\title{
Erratum to: Expression of REG la gene in type 2 diabetics in Pakistan
}

\author{
Sadaf Saleem Uppal ${ }^{1 *}$, Abdul Khaliq Naveed ${ }^{2}$, Saeeda Baig ${ }^{3}$ and Bushra Chaudhry ${ }^{4}$
}

\section{Erratum to: Diabetol Metab Syndr (2015) 7:96 DOI 10.1186/s13098-015-0092-6}

The original version of this article [1] unfortunately contained a mistake in Figure 2. Figure panel $2 \mathrm{c}$ and $2 \mathrm{~d}$ should read as follows:

1. Figure 2c: Spearman $r=0.38$ with no - (negative) sign.

2. Figure $2 \mathrm{~d}$ : Spearman $\mathrm{r}=0.42$ with no - (negative) sign and $\mathrm{p}<0.001$ and not $\mathrm{p}=0.001$.

An updated version of Fig. 2 has been provided below.

The original version of this article has been updated to reflect this change.

\footnotetext{
*Correspondence: sadaf@amcollege.nust.edu.pk

${ }^{1}$ Department of Biochemistry and Molecular Biology, Army Medical

College, Rawalpindi and National University of Science and Technology,

Islamabad, Pakistan

Full list of author information is available at the end of the article
} 

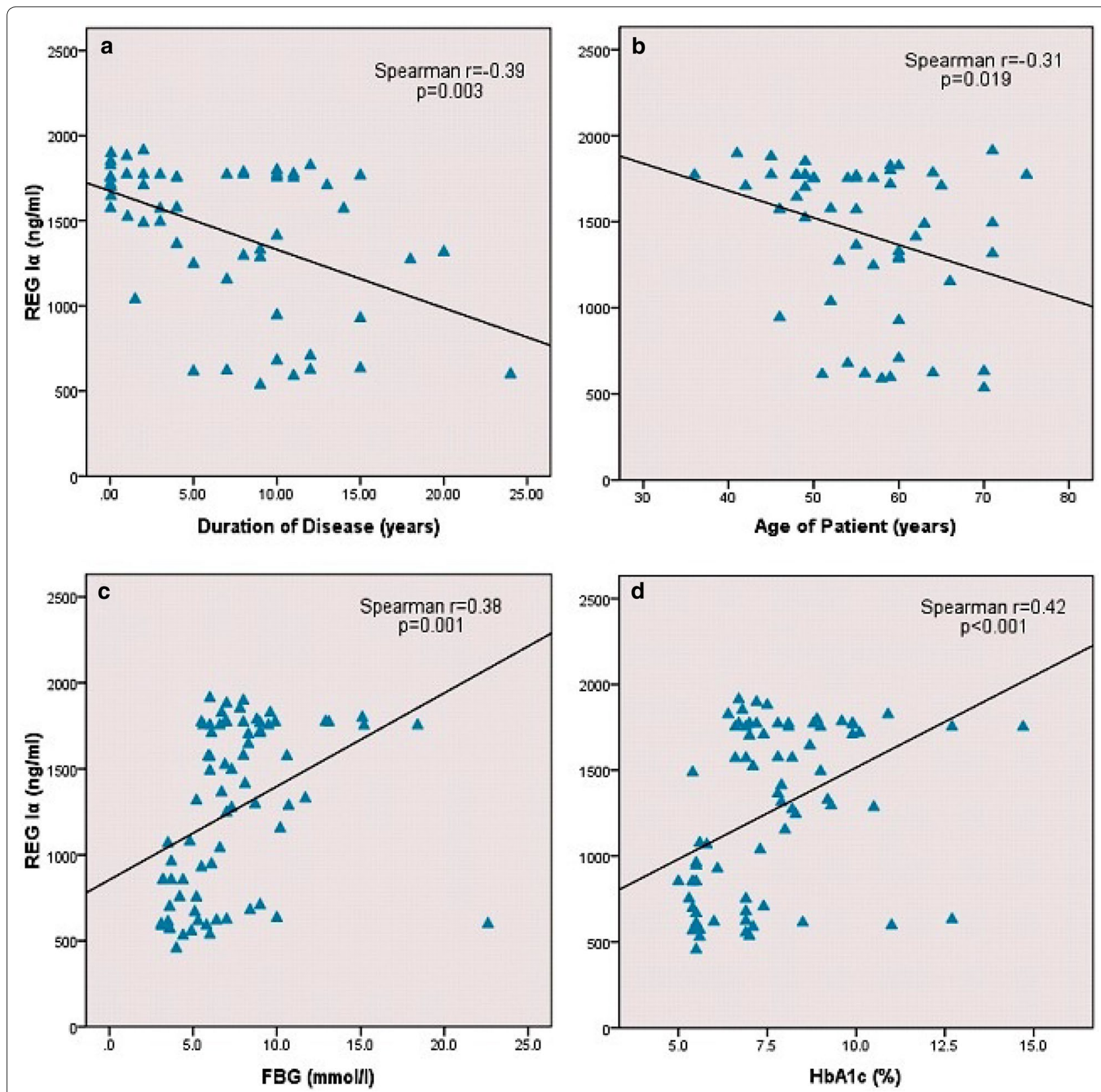

Fig. 2 Correlation between clinical characteristics and serum REG la protein in type 2 diabetes patients. a Correlation between disease duration and serum REG la protein. b Correlation between age of patient and serum REG la protein in type 2 diabetes patients. correlation between FBG and serum REG la protein in type 2 diabetes patients. $\mathbf{d}$ Correlation between HbA1c and serum REG la protein in type 2 diabetes patients

\section{Author details}

${ }^{1}$ Department of Biochemistry and Molecular Biology, Army Medical College, Rawalpindi and National University of Science and Technology, Islamabad, Pakistan. ${ }^{2}$ Department of Biochemistry, Islamic International Medical College, Riphah International University, Islamabad, Pakistan. ${ }^{3}$ Department of Biochemistry, Ziauddin University, Karachi, Pakistan. ${ }^{4}$ Department of Biological and Biomedical Sciences, Aga Khan University, Karachi, Pakistan.
Published online: 07 March 2016

\section{Reference}

1. Uppal SS, Naveed AK, Baig S, Chaudhry B. Diabetol Metab Syndr. 2015;7:96. doi:10.1186/s13098-015-0092-6.

The online version of the original article can be found under doi:10.1186/s13098-015-0092-6. 